\title{
Business ethics research in the hospitality industry: topics, methods and trends
}

\author{
Yasin Sehitoglu \\ Department of Business Administration, \\ Faculty of Economic and Administrative Sciences, \\ Yıldız Technical University, \\ Istanbul, 34220, Turkey \\ Email: ysehit@yildiz.edu.tr
}

\section{Gary Ross}

College of Business,

Minot State University,

Minot, ND 58707, USA

Email: gary.ross@minotstateu.edu

\section{Mehmet Ali Köseoglu*}

College of Business Administration,

American University of the Middle East,

Egalia, Kuwait

and

Business School

Y1ldırım Beyazıt University,

Ankara, Turkey

Email: trmaliktr@yahoo.com

*Corresponding author

\begin{abstract}
This study investigates how business ethics research has evolved in hospitality management (HM). This evolution is explored using bibliometrics from articles related to ethics published in HM journals indexed in SSCI. This study provides a broad view on ethics research in HM related to topics discussed, methods employed, and trends. As a first study of HM with a business ethics focus, the findings show several things. First, there has been a significant increase in the number of such articles. Second, the most popular topics are corporate social responsibility and natural environmental issues. Third, quantitative methods and primary data provided by hotels are dominant in many studies; qualitative, hybrid research approaches, and advanced statistical methods have become more common in recent years. Accordingly, referring to the findings related to this study, this article presents limitations of the study and future steps.
\end{abstract}

Keywords: business ethics; codes; hospitality; journals; bibliometric analysis; topics; methods; trends. 
Reference to this paper should be made as follows: Sehitoglu, Y., Ross, G. and Köseoglu, M.A. (2017) 'Business ethics research in the hospitality industry: topics, methods and trends', Int. J. Bibliometrics in Business and Management, Vol. 1, No. 1, pp.80-96.

Biographical notes: Yasin Sehitoglu is an Assistant Professor at the Yildiz Technical University, Istanbul, Turkey. He earned his $\mathrm{PhD}$ in Management and Organisation at Gebze Technical University, Turkey, in 2010. His current research focuses on organisational behaviour and entrepreneurship.

Gary Ross is a Professor of Management at Minot State University. He received his Doctorate in Educational Administration and his Master of Business Administration from the University of North Dakota, and his Bachelor of Arts in Business Administration from Minot State University. He teaches Management and Human Resource Management courses at both the undergraduate and graduate levels. He has completed several consulting projects and also served as a Faculty Development Evaluation Consultant with the Collaboration for the Advancement of College Teaching and Learning in St. Paul, Minnesota. He has presented in several places in the USA, Europe and China.

Mehmet Ali Köseoglu works at the American University of the Middle East, Kuwait. He earned his PhD in Business Administration at Afyon Kocatepe University, Afyonkarahisar, Turkey, in 2007. He is the author of over 90 basic and applied research articles and published presentations in strategic management, bibliometric analysis, and related areas. His current research focuses on business strategy, strategic management, bibliometric analysis, and related topics.

\section{Introduction}

This study aims to explore the evolution of business ethics research by assessing topics, methods, and trends from articles published in leading hospitality oriented journals, including the Cornell Hospitality Quarterly (CHQ), the International Journal of Contemporary Hospitality Management (IJCHM), the International Journal of Hospitality Management (IJHM), and the Journal of Hospitality and Tourism Research (JHTR).

Research on the hospitality industry - an industry in which there is a fiercely competitive environment, sophisticated stakeholders, and much interaction with the economy - has been growing considerably. This growth has been evaluated by researchers to illustrate what we have already investigated and what we should investigate in the future. There are several reviews or bibliometric analysis studies that have assessed the knowledge domain of hospitality research. Reviews or bibliometric analysis studies in the tourism and hospitality industry were classified by Köseoglu et al. (2015) into six categories: Journals Assessment and Ranking Studies (e.g., Cheng et al., 2011; Ryan, 2005; Svensson et al., 2009a, 2009b; McKercher, 2005), Article Identification Studies (e.g., Park et al., 2011; Zhao and Ritchie, 2007), Content Analysis Studies (e.g. Ballantyne et al., 2009; Rivera and Upchurch, 2008), Citation Analysis 
Studies (e.g., Wardle and Buckly, 2014; Ye et al., 2012), Disciplinal Relationship Analysis Studies (e.g., Harrington et al., 2014; Harrington and Ottenbacher, 2011; Barrios et al., 2008), and Country Research Analysis Studies (e.g., Benckendorff, 2009; Tsang and Hsu, 2011; Xie, 2003). Even with this increasing abundance, there is no study in the hospitality management or business ethics literature evaluating the progress or level of business ethics in the hospitality industry based on topics, methods, trends, and journals.

Business ethics is a sensitive topic since it involves decisions about whether business actions are 'good or bad' or 'right or wrong' based on morals or codes. These decisions either directly or indirectly influence performance (Elms et al., 2010; Foss, 1997; Gilbert, 1986; Hosmer, 1994; Vogel, 1991; Miles, 1993; Husted and Allen, 2000). Hence, whether businesses are successful or not, ethical questions arise. As previously mentioned, the hospitality industry has fierce competitive environments; knowledgeable customers, employees, and organisations; and interacts continuously with the economy. As a result, the hospitality industry frequently encounters ethical issues. This inspires more research questions in the area of business ethics. Hence, business ethics research in the hospitality industry has been predictably growing. To identify the current state and to generate new directions for researchers, academicians, professionals, and editors, the growth of business ethics research in the hospitality industry should be investigated. Therefore, this study addresses how business ethics research in the hospitality literature has progressed and it also generates new research agendas for the future. This study analyses topics and research methods employed by examining trends based in selected journal between two periods (2001-2007 and 2008-2014). With this mind, the main purposes of this study are to:

- identify the frequency of articles related to business ethics in hospitality journals, delineate how the frequencies changed in recent years, and determine the percentages of articles published in the journals

- identify the most popular topics in the articles by journal and how this has changed across time

- $\quad$ define what kind (e.g., empirical or conceptual, qualitative, quantitative, or hybrid) of articles were published most frequently, what methodical procedures (e.g., primary data or secondary data,) were used in empirical articles, and whether there were any changes in usages of methods during between the two time periods by journal

- identify what research samples (hotels, restaurants, shopping malls, etc.) were the most common and what countries were selected for these studies

- present the statistical techniques that were used in the articles and how the usage of these techniques changed by journal and year.

The identification of the frequency of articles related to business ethics in hospitality journals can be a measure of how focused the industry is on ethical issues and whether the industry is taking ethical challenges seriously. In addition, the identification of the most popular topics can highlight where the research priorities are in the industry. This can, also, help identify ethics topics that should be researched more thoroughly. The sophistication of the research and statistical methods employed can help researchers 
identify areas for further development which can result in a greater maturity of research and analysis. The identification of most commonly selected research samples and countries can help researchers assess the representativeness and generalisability of various research findings. In addition, this information can help researchers expand the scope of the body of knowledge in the literature.

This paper is organised as follows: first, the methodology section of this paper explains how the journals were selected, how the data were collected, and how these data were analysed. Second, the findings are presented based on frequency and content of articles by journal and by period. Finally, this paper offers an inclusive evaluation of the results and limitations of this analysis and suggestions for future research.

\section{Methodology}

\subsection{A database and journals selection}

Articles from peer-reviewed journals were selected because they had been accepted as possessing 'certified knowledge' (Ramos-Rodriguez and Ruis-Navarro, 2004). This approach enhances the reliability of results that were generated by using bibliometric analysis. Therefore, the Social Science Citation Index (SSCI) database - which consists exclusively of peer-reviewed articles - was selected due to its reputation and importance in the academic world.

These researchers selected four leading hospitality oriented journals from the SSCI database. These journals were selected because they have been identified as leading journals in the hospitality industry (Harrington and Ottenbacher, 2011; Yoo, Lee, and Bai, 2011; Law and Van der Veen, 2009; McKercher et al., 2006) based on their impact factors (Journal of Citation Reports, 2015). These journals are listed below:

\section{- Cornell Hospitality Quarterly (CHQ)}

- International Journal of Contemporary Hospitality Management (IJCHM)

- International Journal of Hospitality Management (IJHM)

- Journal of Hospitality and Tourism Research (JHTR).

\subsection{Data collection}

The articles related to business ethics in the leading hospitality journals were accessed by searching keywords, including corruption, morality, reputation management, corporate social responsibility, glass ceiling/gender equality, ethical decision-making, white-collar crime, insider trading, environmental issues (natural environment), codes of ethics (Robertson, 2008), business ethics, corporate ethics, social responsibility, social performance, corporate citizenship, and social responsiveness (Ma, 2009) without a time limit.

Two authors individually assessed the articles to determine whether they focused on business ethics in the hospitality industry by asking, "Does the article directly or 
indirectly relate to business ethics in hospitality activities"? If the authors responded in the affirmative, the article was accepted for the subsequent steps of the study. The authors ensured data validity and reliability (inter-rater) by reaching consensuses on the articles selected.

\subsection{Analysis}

The analysis presented the distribution of articles by journal and year and the content of each article, including its research theme, article type, research methods (primary or secondary data), statistical techniques, and populations sampled. Based on articles deemed descriptive of business ethics in the hospitality industry, the sample included articles published between 1996 and 2014. Five articles were published between 1996 and 1999; due to this small number, these five articles were added to the group of articles published in 2001 and, throughout this paper, we refer to this as the 2001-2007 period. Thus, the articles were divided into two equal and consecutive seven-year sub-periods (2001-2007 and 2008-2014) to illustrate the evolution of the field in hospitality.

\section{Results and discussion}

\subsection{Frequency of business ethics research in leading hospitality journals by year}

As seen in Table 1, business ethics articles published in leading hospitality journals by year, a total of 94 business ethics articles were published in the four leading hospitality journals between 1996 and 2014. The IJHM published the most articles $(63.83 \%)$, followed by the IJCHM (17.02\%), and then the JHTR (10.64\%). The CHQ published the fewest $(8.51 \%)$.

Table 1 Business ethics articles published in leading hospitality journals by year

\begin{tabular}{|c|c|c|c|c|c|c|c|c|c|c|}
\hline \multirow{3}{*}{ Years } & \multicolumn{8}{|c|}{ Journals } & \multirow{2}{*}{\multicolumn{2}{|c|}{ Total }} \\
\hline & \multicolumn{2}{|c|}{$\mathrm{CHQ}$} & \multicolumn{2}{|c|}{ IJCHM } & \multicolumn{2}{|c|}{ IJHM } & \multicolumn{2}{|c|}{ JHTR } & & \\
\hline & $n$ & $\%$ & $n$ & $\%$ & $n$ & $\%$ & $n$ & $\%$ & $n$ & $\%$ \\
\hline 1996 & - & - & 1 & 6.3 & - & - & - & - & 1 & 1.1 \\
\hline 1998 & - & - & 1 & 6.3 & 1 & 1.7 & - & - & 2 & 2.1 \\
\hline 1999 & 1 & 12.5 & - & - & - & - & 1 & 10.0 & 2 & 2.1 \\
\hline 2001 & - & - & - & - & 1 & 1.7 & 1 & 10.0 & 2 & 2.1 \\
\hline 2002 & - & - & - & - & 1 & 1.7 & - & - & 1 & 1.1 \\
\hline 2003 & - & - & - & - & 1 & 1.7 & - & - & 1 & 1.1 \\
\hline
\end{tabular}


Table 1 Business ethics articles published in leading hospitality journals by year (continued)

\begin{tabular}{|c|c|c|c|c|c|c|c|c|c|c|}
\hline \multirow{3}{*}{ Years } & \multicolumn{8}{|c|}{ Journals } & \multirow{2}{*}{\multicolumn{2}{|c|}{ Total }} \\
\hline & \multicolumn{2}{|c|}{$\mathrm{CHQ}$} & \multicolumn{2}{|c|}{ IJCHM } & \multicolumn{2}{|c|}{ IJHM } & \multicolumn{2}{|c|}{ JHTR } & & \\
\hline & $n$ & $\%$ & $n$ & $\%$ & $n$ & $\%$ & $n$ & $\%$ & $n$ & $\%$ \\
\hline 2004 & - & - & 2 & 12.5 & 1 & 1.7 & - & - & 3 & 3.2 \\
\hline 2005 & 1 & 12.5 & 1 & 6.3 & 1 & 1.7 & - & - & 3 & 3.2 \\
\hline 2006 & - & - & 3 & 18.8 & 1 & 1.7 & - & - & 4 & 4.3 \\
\hline 2007 & - & - & 1 & 6.3 & 3 & 5.0 & - & - & 4 & 4.3 \\
\hline 2008 & - & - & 1 & 6.3 & 3 & 5.0 & 1 & 10.0 & 5 & 5.3 \\
\hline 2009 & 1 & 12.5 & 1 & 6.3 & 3 & 5.0 & 1 & 10.0 & 6 & 6.4 \\
\hline 2010 & - & - & 1 & 6.3 & 3 & 5.0 & 1 & 10.0 & 5 & 5.3 \\
\hline 2011 & - & - & 1 & 6.3 & 3 & 5.0 & - & - & 4 & 4.3 \\
\hline 2012 & 1 & 12.5 & 1 & 6.3 & 10 & 16.7 & 1 & 10.0 & 13 & 13.8 \\
\hline 2013 & 3 & 37.5 & 1 & 6.3 & 12 & 20.0 & 1 & 10.0 & 17 & 18.1 \\
\hline 2014 & 1 & 12.5 & 1 & 6.3 & 16 & 26.7 & 3 & 30.0 & 21 & 22.3 \\
\hline Total & 8 & 100 & 16 & 100 & 60 & 100 & 10 & 100 & 94 & 100.0 \\
\hline$\%$ & \multicolumn{2}{|c|}{8.51} & \multicolumn{2}{|c|}{17.02} & \multicolumn{2}{|c|}{63.83} & \multicolumn{2}{|c|}{10.64} & \multicolumn{2}{|c|}{100.0} \\
\hline
\end{tabular}

Table 2 Themes of articles by journal

\begin{tabular}{|c|c|c|c|c|c|c|c|c|c|c|}
\hline \multirow{3}{*}{ Themes } & \multicolumn{8}{|c|}{ Journals } & \multirow{2}{*}{\multicolumn{2}{|c|}{ Total }} \\
\hline & \multicolumn{2}{|c|}{$\mathrm{CHQ}$} & \multicolumn{2}{|c|}{ IJCHM } & \multicolumn{2}{|c|}{ IJHM } & \multicolumn{2}{|c|}{ JHTR } & & \\
\hline & $n$ & $\%$ & $n$ & $\%$ & $n$ & $\%$ & $n$ & $\%$ & $n$ & $\%$ \\
\hline Corruption & - & - & - & - & - & - & 1 & 10.0 & 1 & 1.1 \\
\hline Morality & - & - & - & - & - & - & - & - & - & - \\
\hline Reputation management & 1 & 12.50 & - & - & - & - & 1 & 10.0 & 2 & 2.1 \\
\hline $\begin{array}{l}\text { Corporate social } \\
\text { responsibility }\end{array}$ & 3 & 37.5 & 7 & 43.8 & 27 & 45.0 & 3 & 30.0 & 40 & 42.6 \\
\hline $\begin{array}{l}\text { Glass ceiling/gender } \\
\text { equality }\end{array}$ & 2 & 25.0 & 1 & 6.3 & 3 & 5.0 & 1 & 10.0 & 7 & 7.4 \\
\hline Ethical decision-making & - & - & 1 & 6.3 & 2 & 3.3 & - & - & 3 & 3.2 \\
\hline White-collar crime & - & - & - & - & - & - & - & - & - & - \\
\hline Insider trading & - & - & - & - & - & - & - & - & - & - \\
\hline $\begin{array}{l}\text { Environmental issues } \\
\text { (natural environment) }\end{array}$ & 2 & 25.0 & 6 & 37.5 & 23 & 38.3 & 2 & 20.0 & 33 & 35.1 \\
\hline Codes of ethics & - & - & - & - & 2 & 3.3 & - & - & 2 & 2.1 \\
\hline Business ethics & - & - & 1 & 6.3 & 2 & 3.3 & - & & 3 & 3.2 \\
\hline Corporate ethics & - & - & - & - & - & - & - & - & - & - \\
\hline Social performance & - & - & - & - & - & - & - & - & - & - \\
\hline Corporate citizenship & - & - & - & - & - & - & - & - & - & - \\
\hline Social responsiveness & - & - & - & - & 1 & 1.7 & 2 & 20.0 & 3 & 3.2 \\
\hline Total & 8 & 100 & 16 & 100 & 60 & 100 & 10 & 100 & 94 & 100 \\
\hline
\end{tabular}




\subsection{Content of reviewed articles}

\subsubsection{Research themes}

Table 2, themes of articles by journal, presents the themes of the 94 articles examined in this study. The three most popular themes, in descending order of popularity, were corporate social responsibility, environmental issues (natural environment), and glass ceiling/gender equality. Approximately $42.6 \%$ of articles reflected a corporate social responsibility theme, $35.1 \%$ reflected an environmental issues (natural environment) theme, and $7.4 \%$ a glass ceiling/gender equality theme.

These same top three themes were identified by Köseoglu et al. (2015) in their study of a broader selection of journals in the tourism and hospitality industry, although in a different order. In that study, environmental issues (natural environment) was the most popular theme followed closely by corporate social responsibility, then, at some distance, glass ceiling/gender equality issues. Köseoglu et al. (2015) compared the findings of that study to those of Robertson (2008) who indicated that environmental issues, ethical policies and planning, and reputation management were the top three ethical themes. In addition, Köseoglu et al. (2015) contrasted their findings with those of Enver and Kozak (2014) who identified environmental management as a lower priority.

Figure 1, business ethics research themes in all journals by sub-period, presents the popularity of themes in articles published in the journals during the 2001-2007 and 2008-2014 time periods. It appears that there was a substantial increase with two themes. During the first time period, only three articles reflected the social responsibility theme. However, during the second time period, there were 37 such articles. The environmental issues (natural environment) theme increased from 12 during the first time period to 21 during the second. A somewhat similar pattern was identified by Köseoglu et al. (2015) in that the corporate social responsibility and the environmental issues displayed growth patterns over time.

Figure 1 Business ethics research themes in all journals by sub-period (see online version for colours)

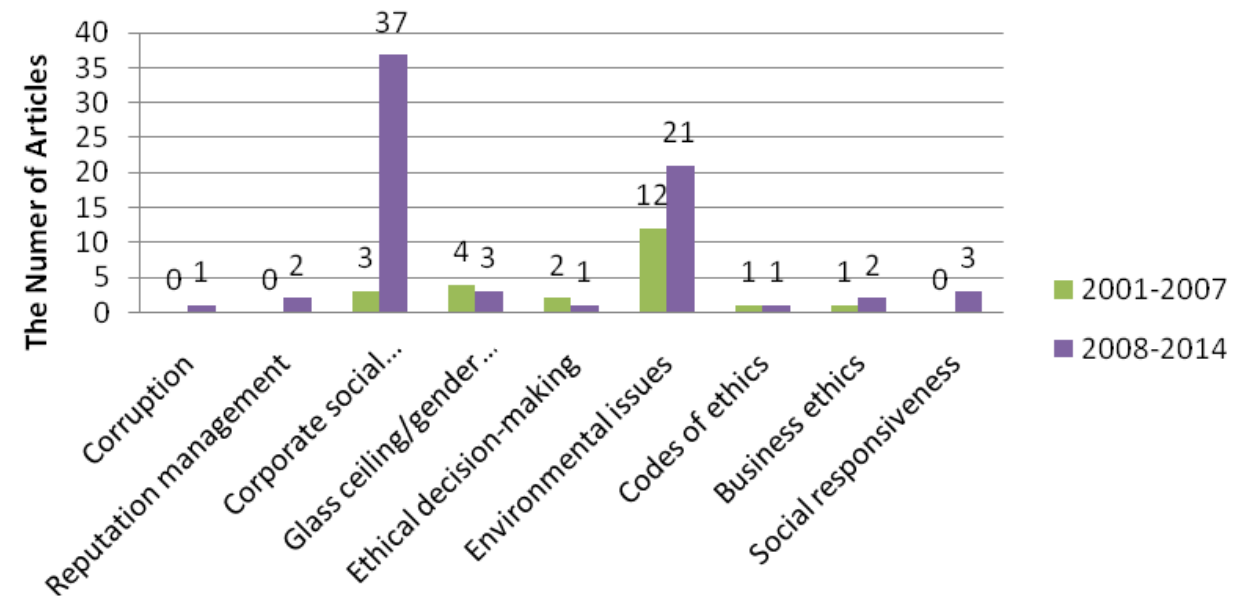


When each journal was examined, significant points emerged. For instance, the trend of the three most popular themes previously identified for all journals basically held true for articles published in the $C H Q, I J C H M$, and IJHM over this entire time period. The most popular theme is corporate social responsibility ( $37.5 \%$ of articles in the $C H Q)$. However, environmental issues (natural environment) and glass ceiling/gender equality are tied for the second most popular theme at $25.0 \%$ each. When comparing the themes between the two time periods, however, there are two differences. There were no corporate social responsibility articles published in this journal during the first time period; all three such articles were published during the second time period. Likewise, there were no reputation articles published in this journal during the first time period; the only such article was published during the second time period. For the glass ceiling/gender equality and environmental issues (natural environment) themes, the number of articles published in both time periods was the same.

The most popular theme is corporate social responsibility ( $43.8 \%$ of articles in the $I J C H M$ ) and the second most popular theme is environmental issues (natural environment) (37.5\%). However, glass ceiling/gender equality, ethical decision-making, and business ethics themes are tied for the third most popular theme at $6.3 \%$ each. When comparing the themes between the two time periods, some differences exist. The corporate social responsibility theme increased from two articles during the first time period to five during the second. The environmental issues (natural environment) theme decreased from four during the first time period to two during the second. In addition, during the first time period, there was one article published for the glass ceiling/gender equality, ethical decision-making, and business ethics themes during the first time period but none during the second.

When comparing the themes published in IJHM between the two time periods, there are two striking differences. The corporate social responsibility theme increased from one during the 2001-2007 period to 26 during the 2008-2014 period. Likewise, the environmental issues (natural environment) theme increased from six during the first time period to 17 during the second.

Overall, as with the popularity of themes published in JHTR, the corporate social responsibility theme was the most popular theme. The environmental issues (natural environment) and social responsiveness issues were tied for the second most popular themes. When comparing the themes between the two time periods, the corporate social responsibility theme, once again, reflected an increase. During the first time period, there were no articles published in the JHTR during the first time period reflecting the corporate social responsibility theme but three during the second time period. The social responsibility theme increased from zero in the first time period to two in the second.

\section{Nature of business ethics articles related to $T / H$}

Table 3, nature of articles by journal, presents the nature of the business ethics articles by journal. The first section of Table 3 presents the article types. Approximately $96.8 \%$ of business ethics articles examine were original articles; only 3.2\% were research notes. All of the articles in three of the journals (CHQ, IJCHM, and JHTR) were original; $95.0 \%$ in the $I J H M$ were original. It appears that there is a strong preference for original articles. This is consistent with the findings of the Köseoglu et al. (2015) study of a broader selection of journals (97.8\% were original articles) and the study Köseoglu et al. (2015) in Turkey ( $88.9 \%$ were original articles). 
Next, Table 3 displays the methods employed. The vast majority $(85.1 \%)$ were empirical articles with $13.8 \%$ begin conceptual and $1.1 \%$ review articles. All of the articles in the JHTR were empirical. The IJCHM had the lowest percentage (62.5) of empirical articles. This is fairly consistent with the findings of several other studies. The Köseoglu et al. (2015) study, 73.2\% were empirical, $25.1 \%$ conceptual, and 1.7\% reviews. Several other studies (Mehmetoglu, 2004; Mohammed et al., 2015; Köseoglu et al., 2015; Enver and Kozak, 2014; Tsang and Hsu, 2011; Baloglu and Assante, 1999) all reported a dominance of empirical articles, ranging from a low of $58.0 \%$ to a high of $96.3 \%$.

Table 3 also presents the percent of articles that were of a quantitative, qualitative, or hybrid nature. Approximately $69.1 \%$ of all articles were quantitative, ranging from a high of 90.0 in the JHTR to a low of $37.5 \%$ in the IJCHM. Three of the four journals appear to publish more quantitative articles. There appears to be a similar dominance of quantitative studies reported by several other studies, including Köseoglu et al. (2015), Mehmetoglu (2004), Mohammed et al. (2015), Myung et al. (2012) and Tsang and Hsu (2011). The percent quantitative in these studies ranges from a high of $93.2 \%$ to a low of $54 \%$.

Table 3 Nature of articles by journal

\begin{tabular}{|c|c|c|c|c|c|c|c|c|c|c|}
\hline \multirow{3}{*}{ Category } & \multicolumn{8}{|c|}{ Journals } & \multirow{2}{*}{\multicolumn{2}{|c|}{ Total }} \\
\hline & \multicolumn{2}{|c|}{$\mathrm{CHQ}$} & \multicolumn{2}{|c|}{ IJCHM } & \multicolumn{2}{|c|}{ IJHM } & \multicolumn{2}{|c|}{ JHTR } & & \\
\hline & $n$ & $\%$ & $n$ & $\%$ & $n$ & $\%$ & $n$ & $\%$ & $n$ & $\%$ \\
\hline \multicolumn{11}{|l|}{ Article type } \\
\hline Original article & 8 & 100 & 16 & 100 & 57 & 95.0 & 10 & 100 & 91 & 96.8 \\
\hline Research note & - & - & - & - & 3 & 5.0 & - & - & 3 & 3.2 \\
\hline \multicolumn{11}{|l|}{ Methods of the article } \\
\hline Empirical & 7 & 87.5 & 10 & 62.5 & 53 & 88.3 & 10 & 100 & 80 & 85.1 \\
\hline Conceptual & 1 & 12.5 & 6 & 37.5 & 6 & 10.0 & - & - & 13 & 13.8 \\
\hline Review & - & - & - & - & 1 & 1.7 & - & - & 1 & 1.1 \\
\hline \multicolumn{11}{|l|}{ Research methods } \\
\hline Quantitative & 6 & 75.0 & 6 & 37.5 & 44 & 73.3 & 9 & 90.0 & 65 & 69.1 \\
\hline Qualitative & 1 & 12.5 & 10 & 62.5 & 9 & 15.0 & - & - & 20 & 21.3 \\
\hline Hybrid & 1 & 12.5 & - & - & 7 & 11.7 & 1 & 10.0 & 9 & 9.6 \\
\hline \multicolumn{11}{|l|}{$\begin{array}{l}\text { Primary or secondary } \\
\text { data }\end{array}$} \\
\hline Primary-questionnaire & 6 & 75.0 & 3 & 18.8 & 31 & 51.7 & 8 & 80.0 & 48 & 51.0 \\
\hline Primary-interview & - & - & 4 & 25.0 & 2 & 3.3 & - & - & 6 & 6.4 \\
\hline Primary-case study & - & - & 2 & 12.5 & 2 & 3.3 & - & - & 4 & 4.3 \\
\hline Primary-observation & - & - & 1 & 6.2 & 3 & 5.0 & - & - & 4 & 4.3 \\
\hline $\begin{array}{l}\text { Primary-hybrid ( } 2 \text { or } \\
\text { more primary sources) }\end{array}$ & 1 & 12.5 & - & - & 3 & 5.0 & 1 & 10.0 & 5 & 5.3 \\
\hline Secondary & - & - & 6 & 37.5 & 14 & 23.3 & 1 & 10.0 & 21 & 22.3 \\
\hline $\begin{array}{l}\text { Secondary-primary } \\
\text { (at least one each) }\end{array}$ & 1 & 12.5 & - & - & 5 & 8.3 & - & - & 6 & 6.4 \\
\hline
\end{tabular}


Table 3 Nature of articles by journal (continued)

\begin{tabular}{|c|c|c|c|c|c|c|c|c|c|c|}
\hline \multirow{3}{*}{ Category } & \multicolumn{8}{|c|}{ Journals } & \multirow{2}{*}{\multicolumn{2}{|c|}{ Total }} \\
\hline & \multicolumn{2}{|c|}{$\mathrm{CHQ}$} & \multicolumn{2}{|c|}{ IJCHM } & \multicolumn{2}{|c|}{ IJHM } & \multicolumn{2}{|c|}{ JHTR } & & \\
\hline & $n$ & $\%$ & $n$ & $\%$ & $n$ & $\%$ & $n$ & $\%$ & $n$ & $\%$ \\
\hline \multicolumn{11}{|l|}{ Statistical techniques } \\
\hline $\begin{array}{l}\text { Variance analysis } \\
\text { (An(c)ova, Manova) }\end{array}$ & - & - & 1 & 7.7 & 15 & 13.6 & 1 & 3.6 & 17 & 10.4 \\
\hline Descriptive/content & 2 & 16.7 & 7 & 53.8 & 21 & 19.1 & 2 & 7.1 & 32 & 19.6 \\
\hline $\begin{array}{l}\text { t-test, } \chi^{2} \text {, correlation, } \\
\text { Man U }\end{array}$ & 4 & 33.3 & 1 & 7.7 & 32 & 29.1 & 15 & 53.6 & 52 & 31.9 \\
\hline Regression & 1 & 8.3 & 3 & 23.1 & 14 & 12.7 & 3 & 10.7 & 21 & 12.9 \\
\hline $\begin{array}{l}\text { Factor, cluster, } \\
\text { discriminant }\end{array}$ & 3 & 25.0 & 1 & 7.7 & 16 & 14.5 & 5 & 17.9 & 25 & 15.3 \\
\hline $\begin{array}{l}\text { Structural equation } \\
\text { model }\end{array}$ & - & - & - & - & 5 & 4.5 & - & - & 5 & 3.1 \\
\hline Others & 2 & 16.7 & - & - & 7 & 6.4 & 2 & 7.1 & 11 & 6.7 \\
\hline \multicolumn{11}{|l|}{ Samples as industries } \\
\hline Airlines & - & - & - & - & - & - & 1 & 10.0 & 1 & 1.1 \\
\hline Casino & - & - & - & - & 2 & 3.3 & - & - & 2 & 2.1 \\
\hline $\begin{array}{l}\text { General hospitality } \\
\text { industry }\end{array}$ & - & - & - & - & 1 & 1.7 & - & - & 1 & 1.1 \\
\hline $\begin{array}{l}\text { General tourism } \\
\text { destinations/org. }\end{array}$ & - & - & 1 & 6.3 & 4 & 6.7 & 2 & 20.0 & 7 & 7.4 \\
\hline Hotels & 5 & 62.5 & 12 & 75.0 & 40 & 68.7 & 5 & 50.0 & 62 & 66.0 \\
\hline $\begin{array}{l}\text { Restaurants/food } \\
\text { services }\end{array}$ & 2 & 25.0 & - & - & 7 & 11.7 & - & - & 9 & 9.6 \\
\hline Travellers, visitors & 1 & 12.5 & 2 & 12.5 & 6 & 10.0 & 2 & 20.0 & 11 & 11.7 \\
\hline No sample & - & - & 1 & 6.3 & - & - & - & - & 1 & 1.1 \\
\hline \multicolumn{11}{|l|}{ Samples as a country } \\
\hline Developed countries & 7 & 100 & 9 & 56.3 & 35 & 59.3 & 8 & 88.9 & 59 & 64.8 \\
\hline Developing countries & - & - & 6 & 37.5 & 23 & 39.0 & 1 & 11.1 & 30 & 33.0 \\
\hline Mixed sample & - & - & 1 & 6.3 & 1 & 1.7 & - & - & 2 & 2.2 \\
\hline
\end{tabular}

The data-gathering approaches (primary, secondary, or a combination) are also presented in Table 3. Approximately $71.3 \%$ of all articles utilised primary data-gathering techniques, $22.3 \%$ secondary techniques, and $6.4 \%$ a combination. The $C H Q$ had the highest percentage $(87.5 \%)$ of articles representing primary data with the IJCHM the lowest $(62.5 \%)$. Even with this range, all four journals appear to prefer the use of primary data.

A review of data-gathering approaches in the relevant literature (Köseoglu et al., 2015; Mehmetoglu, 2004; Myung et al., 2012; Law et al., 2014; Baloglu and Assante, 1999; Tsang and Hsu, 2011) reveals some variance, ranging from a high of $87.9 \%$ to a low of $23.2 \%$ employing primary approaches. 
The statistical techniques employed are also presented in Table 3. The most commonly used techniques consisted of t-tests, chi-square, correlation, and Mann-Whitney U test (Man U) (31.9\%). Descriptive statistics were the second most commonly used techniques $(19.6 \%)$ followed by factor, cluster, and discriminant analyses (15.3\%). T-tests, chi-square, correlation, and Mann-Whitney U test were the most commonly used statistical technique in all but one journal, the IJCHM. In that journal, descriptive statistics were the most commonly used technique. Factor, cluster, and discriminant analysis were the second most commonly used technique in the $C H Q$ and the JHTR.

Köseoglu et al. (2015) identified the same top three statistical techniques but in a different order of popularity. Most popular were t-tests, Chi Square, correlation, and Mann-Whitney U test; second, factor, cluster, and discriminant analysis; and then, descriptive and content statistics. Descriptive statistics were the most popular statistical techniques, followed by factor and cluster analysis in several other studies (Mohammed et al., 2015; Myung et al., 2012; Köseoglu et. al., 2015; Baloglu and Assante, 1999; Tsang and Hsu, 2011).

Table 3 also presents the industries sampled in the articles examined. Overall, the hotels were the most popular industry sampled $(66.0 \%)$ followed by travellers and visitors $(11.7 \%)$ and restaurants/food services $(9.6 \%)$. In all four journals separately, hotels were the most popular industry sampled. Restaurants and food services were the second choice in two of the journals $(C H Q$ and $I J H M)$. These findings are similar, with some variation to those of other findings (Köseoglu et al., 2015; Mohammed et al., 2015; Law et al., 2014; Baloglu and Assante, 1999), the range being from a high of 66.3 to a low of $31.8 \%$.

Finally, Table 3 also presents the countries sampled. The majority (64.8\%) of articles focused on developed countries. This holds true for each of the individual journals with a range of $100.0 \%$ in the $C H Q$ to $56.3 \%$ in the $I J C H M$. Although there appears to be a fairly strong preference for business ethics research in developed countries, at least two journals publish a significant percentage of articles that focus on developing countries. A similar preference for sampling developed countries was found by Köseoglu et al. (2015), Mohammed et al. (2015) and Myung et al. (2012), ranging from 53.5 to $63.2 \%$.

During the entire period from 2001 to 2014, there were 94 business articles published in the four journals selected for this study. Twenty-three $(24.5 \%)$ of these articles were published during the first sub-period (2001-2007) and $71(75.5 \%)$ during the second sub-period (2008-2014). During the entire period, there were only three research notes published and 91 original articles. All of the articles published during the first sub-period were original. Approximately $95.8 \%$ of the articles published during the second sub-period were original with $4.2 \%$ being research notes. It does not appear, however, that there is a significant trend from the first to the second sub-period in the direction of more research notes.

During the entire period (2001-2014), 80 (85.1\%) of all business ethics articles in this study were empirical, $13(13.8 \%)$ conceptual, and $1(1.1 \%)$ review. During the first sub-period, approximately $69.6 \%$ of all articles were empirical; however, during the second sub-period, approximately $90.1 \%$ were empirical. It appears that there was some movement in the direction of more empirical articles from the first to the second sub-period. However, this is likely due to the relatively stable and small number of conceptual and review articles in both sub-periods. Quantitative articles represented approximately $52.5 \%$ of all articles examined from the first sub-period; they represented 
approximately $74.6 \%$ of all articles during the second sub-period. Qualitative articles, on the other hand, seemed to decline from the first $(39.1 \%)$ to the second $(15.5 \%)$ subperiod. Hybrid articles displayed a slight increase from $8.7 \%$ to $9.9 \%$. It appears that there was a greater emphasis on quantitative studies during the second sub-period, realised at the expense of qualitative studies.

Figure 2, data-gathering techniques by sub-period, presents the data-gathering techniques employed in the articles examined by sub-period. During the entire period (2001 to 2014), approximately $71.3 \%$ of all articles studied employed the use of primary data, approximately $22.3 \%$ used secondary data, and $6.4 \%$ data from utilising both data-gathering techniques. These percentages did not seem to change significantly between the two sub-periods. Primary data were represented in approximately $73.9 \%$ of articles during the first sub-period and $70.4 \%$ during the second. Likewise, secondary data were represented in $21.7 \%$ during the first and $22.5 \%$ during the second sub-period. Data from both techniques were used in $4.3 \%$ during the first and $7.0 \%$ during the second sub-period.

During the first sub-period, questionnaires $(69.2 \%)$ were the most commonly used primary data-gathering technique, followed by interviews $(23.1 \%)$, and then primary-hybrid (multiple primary methods, 7.7\%). During the second sub-period, questionnaires $(84.8 \%)$ were still the most commonly used primary data-gathering technique but primary-hybrid $(8.7 \%)$ was second, followed by interviews $(6.5 \%)$. The questionnaire method of gathering primary data appears to have gained in popularity with interviews becoming less popular.

Figure 2 Data-gathering techniques by sub-period (see online version for colours)

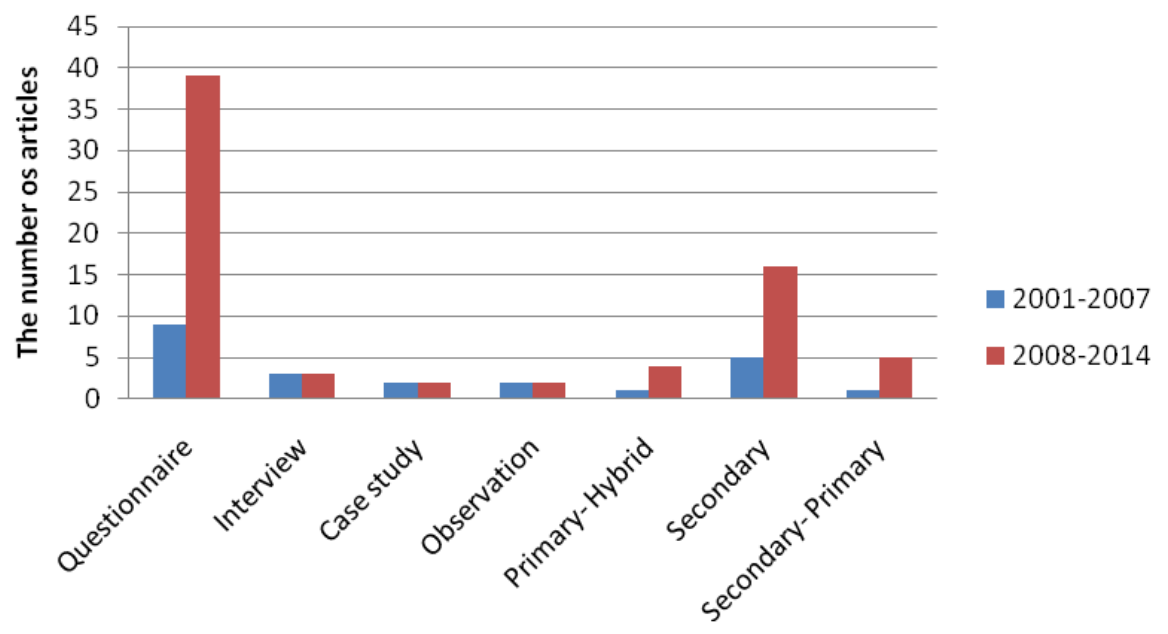

Figure 3, statistical techniques by sub-period, displays the statistical techniques used in business ethics articles by sub-period. During the entire period (2001-2014), the most commonly used statistical technique consisted of t-tests, chi-square, correlation, and Man U; the second consisted of descriptive/content statistics; the third, factor, cluster, and discriminant analysis. During the first sub-period, descriptive/content statistics were the most popular, followed by t-tests, chi-square, correlation, and Man U in second place with regression in third place. During the second sub-period, t-tests, chi-square, 
correlation, and Man U were in first place; followed by descriptive/content statistics in second place; and factor, cluster, and discriminant analysis in third place. It appears that there is a somewhat consistent preference for descriptive/content statistics and the more basic t-tests, chi-square, correlation, and Man U techniques.

Figure 3 Statistical techniques by sub-period (see online version for colours)

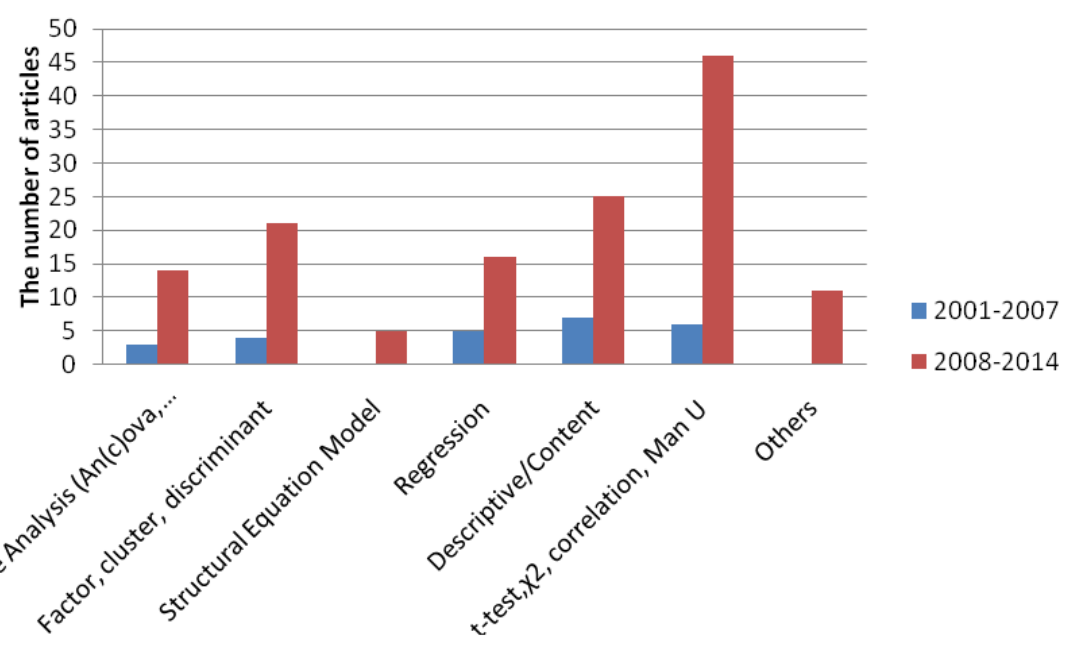

Figure 4, industries sampled by sub-period, presents the industries sampled in the business ethics articles examined. During the entire period (2001-2014), in the vast majority of studies, hotels were the most commonly sampled industry, followed by travelers/visitors, and then by general tourism destinations/organisations. For the most part, this preference for hotels and travelers/visitors is reflected in both sub-periods. The only difference is that, during the second sub-period, restaurants and food services tie for second place with travelers/visitors.

Figure 4 Industries sampled by sub-period (see online version for colours)

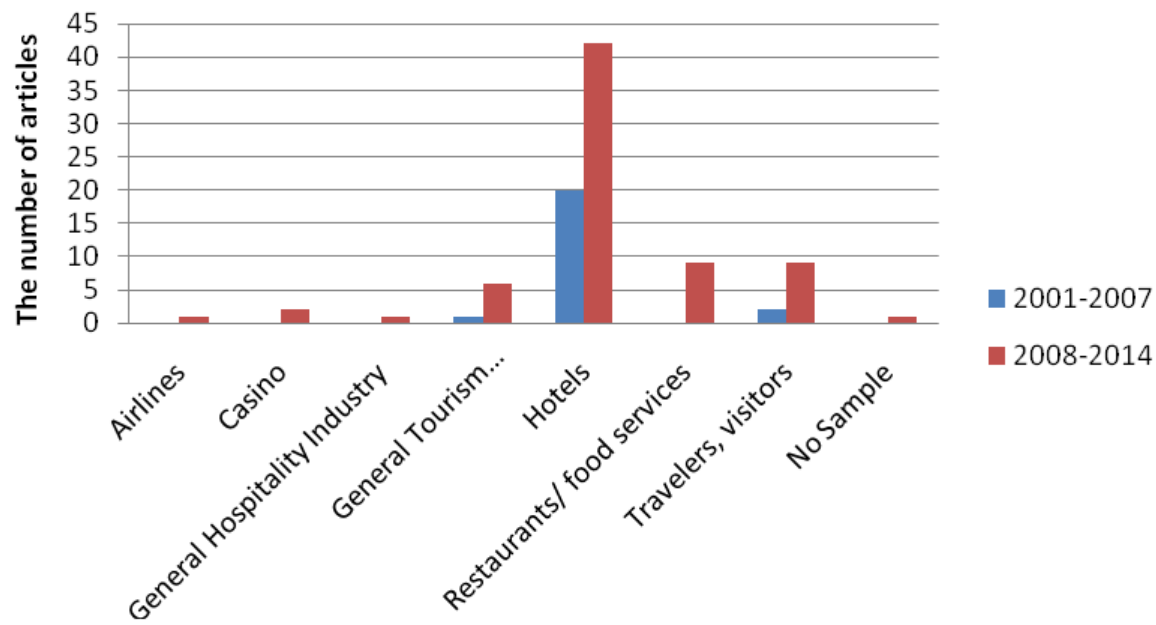


During the entire period (2001-2014), approximately $64.8 \%$ of articles focused on developed countries with $33.0 \%$ on developing countries, and $2.2 \%$ on both. This basic breakdown held fairly steady from the first to the second sub-period. During the first sub-period, approximately $65.2 \%$ of articles focused on developed countries with $34.8 \%$ on developing countries. During the second sub-period, the percentages were 64.7 and 32.4 , respectively, with $2.9 \%$ including both. It appears, therefore, that there is a consistent preference for sampling in developed countries.

\section{Conclusions and implications}

The main purpose of this study was to investigate what business ethics topics in the hospitality industry have been studied in the hospitality literature, what methods have been employed in these studies, and trends in these studies. These issues were explored using bibliometric analysis from articles related to business ethics published in leading hospitality management journals, including the Cornell Hospitality Quarterly, the International Journal of Contemporary Hospitality Management, the International Journal of Hospitality Management, and the Journal of Hospitality and Tourism Research indexed by the Social Sciences Citations Index (SSCI) between 1996 and 2014.

As a first study in the hospitality industry with a business ethics focus, several conclusions have emerged from this analysis. First, the results show that there has been a significant increase in the number of business ethics articles in leading hospitality management journals, particularly in the IJHM in recent years (between 2012 and 2014).

Second, although this significant increase has occurred, a few important business ethics topics, such as morality, white-collar crime, insider trading, corporate ethics, social performance, and corporate citizenship, have not been studied in these journals. On the other hand, the most popular topics were corporate social responsibility and natural environmental issues. When one compares hospitality journals with the general business ethics literature, there has a recent paradigm shift in the direction of corporate social responsibility (Stevens, 1997; Ma, 2009; Tseng et al., 2010). There are a number of studies that thoroughly discuss social responsibility topics although the discussions of the fundamental topics of business ethics topics, including ethics, ethic codes, ethical decision making, and ethics and performance relationship, are rare. This is an opportunity for researchers to bridge the gap.

Third, quantitative methods and primary data provided by hotels were dominant in many studies, and qualitative, hybrid-research approaches and advanced statistical methods have become more common in recent years. However, these methods did not follow experimental approaches used in general mainstream business ethics research. Researchers should consider employing mixed methods as used in business ethics research published in the Journal of Business Ethics. In addition, the use of less common qualitative research methods to conduct business ethics research in the hospitality industry is a significant opportunity for scholars. Also, scholars should utilise new techniques, including scenarios that are more appropriate for ethics studies (Stevens, 2001) and the ethnographic research use of scenarios (Jack et al., 2012) that can be employed to develop conceptual frameworks.

Finally, as seen in the other studies examined (Huang and Hsu, 2008; Baloglu and Assante, 1999; Crawford-Welch and McCleary, 1992), many articles employed quantitative methods and primary data provided by hotels from developed countries. In 
addition, the research has used qualitative, hybrid research approaches and advanced statistical methods in recent years. This progress is important in order to increase the quality of articles and the credibility of the business ethics research pertaining to hospitality practices.

As a result, this paper has a few contributions. The first contribution of this study is that it identifies trends of business ethics research in the hospitality industry from articles published in leading hospitality journals. Second, the findings of the study point out the gap in the literature pertaining to business ethics topics and methods employed. In this respect, it helps both researchers and professionals to identify new research agendas.

There are several limitations of this study. First, as noted by Yoo et al. (2011, pp.529-530), "the process of identifying topic and method categories may be inherently biased". Since it is the first study to review business ethics research with a hospitality focus, its contribution can be limited but still provide insights and directions for future research. Second, this study obtained articles on business ethics from four leading hospitality management journals indexed by SSCI between 1996 and 2014. However, a number of other leading journals oriented toward business ethics, tourism, and general business and management indexed by other databases also publish articles focused on the hospitality industry. These articles should be reviewed to ensure a broad and deep understanding in the field. Third, this study focused only on articles; future studies should include books, theses/dissertations, and conference proceedings (Coughlan, 2001). Finally, basic bibliometric analysis was employed in this study; however, to gain additional insights into the development of business ethics research in the hospitality field, future studies should be conducted via co-occurrences analysis (e.g., co-word, co-authorship, co-citations, etc.; Hirsch, 2005; Leydesdorff, 2001; Vinkler, 2010).

\section{References}

Ballantyne, R., Packer, J. and Axelsen, M. (2009) 'Trends in tourism research', Annals of Tourism Research, Vol. 36, No. 1, pp.149-152.

Baloglu, S. and Assante, L.M. (1999) 'A content analysis of subject areas and research methods used in five hospitality management journals', Journal of Hospitality and Tourism Research, Vol. 23, No. 1, pp.53-70.

Barrios, M., Borrego, A., Vilaginés, A., Ollé, C. and Somoza, M. (2008) 'A bibliometric study of psychological research on tourism', Scientometrics, Vol. 77, No. 3, pp.453-467.

Benckendorff, P. (2009) 'Themes and trends in Australian and New Zealand tourism research: a social network analysis of citations in two leading journals (1994-2007)', Journal of Hospitality and Tourism Management, Vol. 16, No. 1, pp.1-15.

Cheng, C., Li, X., Petrick, J.F. and O'Leary, J.T. (2011) 'An examination of tourism journal development', Tourism Management, Vol. 32, No. 1, pp.53-61.

Coughlan, R. (2001) 'An analysis of professional codes of ethics in the hospitality industry', International Journal of Hospitality Management, Vol. 20, No. 2, pp.147-162.

Crawford-Welch, S. and McCleary, K.W. (1992) 'An identification of the subject areas and research techniques used in five hospitality-related journals', International Journal of Hospitality Management, Vol. 11, No. 2, pp.155-167.

Elms, H., Brammer, S.J., Harris, J.D. and Phillips, R.A. (2010) 'New directions in strategic management and business ethics', Business Ethics Quarterly, Vol. 20, No. 3, pp.401-426.

Enver, S. and Kozak, N. (2014) 'Bibliometric analysis of tourism and hospitality related articles published in Turkey', Anatolia: An International Journal of Tourism and Hospitality Research, Vol. 25, No. 1, pp.61-80. 
Foss, N.J. (1997) 'Ethics, discovery, and strategy', Journal of Business Ethics, Vol. 16, No. 11, pp.1131-1142.

Gilbert, D.R. (1986) 'Corporate strategy and ethics', Journal of Business Ethics, Vol. 5, No. 2, pp.137-150.

Harrington, R. and Ottenbacher, M. (2011) 'Strategic management: an analysis of its representation and focus in recent hospitality research', International Journal of Contemporary Hospitality Management, Vol. 23, No. 4, pp.439-462.

Harrington, R.J., Chathoth, P.K., Ottenbacher, M. and Altinay, L. (2014) 'Strategic management research in hospitality and tourism: past, present and future', International Journal of Contemporary Hospitality Management, Vol. 26, No. 5, pp.778-808.

Hirsch, J.E. (2005) 'An index to quantify an individual's scientific research output', Proceedings of the National Academy of Sciences of the United States of America, Vol. 102, No. 46, pp.16569-16572.

Hosmer, L. (1994) 'Strategic planning as if ethics mattered', Strategic Management Journal, Vol. 15, No. S2, pp.17-34.

Huang, S. and Hsu, C.H.C. (2008) 'Recent tourism and hospitality research in China', International Journal of Hospitality \& Tourism Administration, Vol. 9, pp.267-287.

Husted, B.W. and Allen, D.B. (2000) 'Is it ethical to use ethics as strategy?', Journal of Business Ethics, Vol. 27, Nos. 1-2, pp.21-31.

Jack, G., Greenwood, M. and Schapper, J. (2012) 'Frontiers, intersections and engagements of ethics and HRM', Journal of Business Ethics, Vol. 111, No. 1, pp.1-12.

Köseoglu, M.A., Sehitoglu, Y. and Parnell, J.A. (2015) 'A bibliometric analysis of scholarly work in leading tourism and hospitality journals: the case of Turkey', Anatolia: An International Journal of Tourism and Hospitality Research, Vol. 26, No. 3, pp.359-371, DOI: 10.1080/13032917.2014.963631.

Law, R. and Van der Veen, R. (2009) 'The popularity of prestigious hospitality journals: a Google scholar approach', International Journal of Contemporary Hospitality Management, Vol. 20, No. 2, pp.113-125.

Law, R., Buhalis, D. and Cobanoglu, C. (2014) 'Progress on information and communication technologies in hospitality and tourism', International Journal of Contemporary Hospitality Management, Vol. 26, No. 5, pp.727-750.

Leydesdorff, L. (2001) The Challenge of Scientometrics: The Development, Measurement, and Self-Organization of Scientific Communications, Universal Publishers, Boca Raton, FL.

Ma, Z. (2009) 'The status of contemporary business ethics research: present and future', Journal of Business Ethics, Vol. 90, No. 3, pp.255-265.

McKercher, B. (2005) 'A case for ranking tourism journals', Tourism Management, Vol. 26, No. 5, pp.649-651.

McKercher, B., Law, R. and Lam, T. (2006) 'Rating tourism and hospitality journals', Tourism Management, Vol. 27, No. 6, pp.1235-1252.

Mehmetoglu, M. (2004) 'Quantitative or qualitative? A content analysis of nordic research in tourism and hospitality', Scandinavian Journal of Hospitality and Tourism, Vol. 4, No. 3, pp.176-190.

Miles, G. (1993) 'In search of ethical profits: insights from strategic management', Journal of Business Ethics, Vol. 12, No. 3, pp.219-225.

Mohammed, I., Guillet, B.D. and Law, R. (2015) 'The contributions of economics to hospitality literature: a content analysis of hospitality and tourism journals', International Journal of Hospitality Management, Vol. 44, No. 1, pp.99-110.

Myung, E., McClaren, A. and Li, L. (2012) 'Environmentally related research in scholarly hospitality journals: current status and future opportunities', International Journal of Hospitality Management, Vol. 31, No. 4, pp.1264-1275. 
Park, K., Phillips, W.J., Canter, D.D. and Abbott, J. (2011) 'Hospitality and tourism research rankings by author, university, and country using six major journals: the first decade of the new millennium', Journal of Hospitality and Tourism Research, Vol. 35, No. 3, pp.381-416.

Ramos-Rodriguez, A-R. and Ruiz-Navarro, J. (2004) 'Changes in the intellectual structure of strategic management research: a bibliometric study of the Strategic Management Journal, 1980-2000', Strategic Management Journal, Vol. 25, No. 10, pp.981-1004.

Rivera, M. and Upchurch, R. (2008) 'The role of research in the hospitality industry: a content analysis of the IJHM between 2000 and 2005', International Journal of Hospitality Management, Vol. 27, No. 4, pp.632-640.

Robertson, C.J. (2008) 'An analysis of 10 years of business ethics research in Strategic Management Journal: 1996-2005', Journal of Business Ethics, Vol. 80, No. 4, pp.745-753.

Ryan, C. (2005) 'The ranking and rating of academics and journals in tourism research', Tourism Management, Vol. 26, No. 5, pp.657-662.

Stevens, B. (1997) 'Hotel ethical codes: a content analysis', International Journals of Hospitality Management, Vol. 16, No. 3, pp.261-271.

Stevens, B. (2001) 'Hospitality ethics: responses from human resource directors and students to seven ethical scenarios', Journal of Business Ethics, Vol. 30, No. 3, pp.233-242.

Svensson, G., Svaeri, S. and Einarsen, K. (2009a) 'Empirical characteristics' of scholarly journals in hospitality and tourism research: an assessment', International Journal of Hospitality Management, Vol. 28, No. 3, pp.479-483.

Svensson, G., Svaeri, S. and Einarsen, K. (2009b) 'Scientific identity' of scholarly journals in hospitality and tourism research: review and evaluation', International Journal of Hospitality Management, Vol. 28, No. 4, pp.631-634.

Tsang, N.K.F. and Hsu, C.H.C. (2011) 'Thirty years of research on tourism and hospitality management in China: a review and analysis of journal publications', International Journal of Hospitality Management, Vol. 30, No. 4, pp.886-896.

Tseng, H., Duan, C., Tung, H. and Kung, H. (2010) 'Modern business ethics research: concepts, theories, and relationships', Journal of Business Ethics, Vol. 91, No. 1, pp.587-597.

Vinkler, P. (2010) The Evaluation of Research by Scientometric Indicators, Woodhead Publishing, Abington.

Vogel, D. (1991) 'Business ethics: new perspectives on old problems', California Management Review, Vol. 33, No. 4, pp.101-117.

Wardle, C. and Buckley, R. (2014) 'Tourism citations in other disciplines', Annals of Tourism Research, Vol. 46, No. 3, pp.163-184.

Xie, Y. (2003) 'Tourism and hospitality industry studies: a comparative research between China and the overseas counties', Tourism Tribune, Vol. 18, No. 5, pp.20-25.

Ye, Q., Song, H. and Li, T. (2012) 'Cross-institutional collaboration networks in tourism and hospitality research', Tourism Management Perspectives, Vol. 2, No. 3, pp.55-64.

Yoo, M., Lee, S. and Bai, B. (2011) 'Hospitality marketing research from 2000 to 2009: topics, methods, and trends', International Journal of Contemporary Hospitality Management, Vol. 23, No. 4, pp.517-532.

Zhao, W. and Ritchie, J.R.B. (2007) 'An investigation of academic leadership in tourism research: 1985-2004', Tourism Management, Vol. 28, No. 2, pp.476-490. 